\title{
Hyper-production of a thermotolerant $\beta$-xylosidase by a deoxy-D-glucose and cycloheximide resistant mutant derivative of Kluyveromyces marxianus PPY 125
}

\author{
Muhammad Ibrahim Rajoka* \\ Industrial Biotechnology Division \\ National Institute for Biotechnology and Genetic Engineering \\ P.O. Box 577, Jhang Road \\ Faisalabad, Pakistan \\ Tel: 9241550815 \\ Fax: 9241651472 \\ E-mail:mirajoka@nibge.org \\ Sana Khan \\ Industrial Biotechnology Division \\ National Institute for Biotechnology and Genetic Engineering \\ P.O. Box 577, Jhang Road \\ Faisalabad, Pakistan \\ Tel: 9241651475 \\ Fax: 9241651472 \\ Email: sanakhan@yahoo.com
}

Financial support: These studies were supported by Pakistan Atomic Energy Commission, Islamabad and in part by a grant made by the United States Agency for International Development under PSTC proposal 6-163, USAID grant no. 9365542-G00-89-42-00.

Keywords: enthalpy, entropy, enzyme kinetics, fermentation, induction, thermodynamics..

Production of $\beta$-xylosidase by a cycloheximide and 2deoxy-D-glucose-resistant mutant of Kluyveromyces marxianus PPY125 was studied when cultured on growth media containing galactose, glucose, xylose, cellobiose, sucrose and lactose as carbon sources. Xylose, cellobiose, lactose and sucrose were the key substrates. Both $K$. marxianus PPY125 and its mutant (M 125) supported maximum $\beta$-xylosidase specific product yield $\left(\mathrm{Y}_{\mathrm{P} / \mathrm{X}}\right)$ following growth on xylose. Basal level of activity was observed in non-induced cultures grown on glucose. The mutant produced 1.5 to 2 -fold more $\beta$-xylosidase than that produced by the wild cells. Synthesis of $\beta$-xylosidase was regulated by an induction mechanism in both wild and mutant cells. Addition of glucose did not inhibit the synthesis of $\beta$-xylosidase in both parental and mutant cultures in the presence of corn steep liquor. Partially purified enzyme showed good stability when incubated at $60^{\circ} \mathrm{C}$ and was quite stable at pH 5.0-7.0. Thermodynamic studies revealed that the enzyme derived by the mutant M125 was more thermostable as evidenced by higher midpoint inactivation temperature, lower activation energy demand for $\beta$-xyloside hydrolysis, as well as lower enthalpy and entropy demand for reversible denaturation of enzyme. $\beta$-xylosidase (EC 3.2.1.37) is one of the component enzymes of the hemicellulase complex and is widely distributed in nature. It catalyzes the hydrolysis of alkyland aryl- glycosides as well as xylobiose and xylooligosaccharides to xylose. In industry, it is employed for hydrolysis of bitter compounds from grape fruit during juice extraction and liberation of aroma from grapes during wine making (Manzanares et al. 1999). $\beta$-xylosidase, in synergistic action with endo- $\beta$-xylanases, (EC 3.2.1.8) and debranching enzymes namely $\alpha$-glucuronidases, esterases and glycosidases have potential application in production of biofuels and in the processing of food. Cellulase-free xylanases have an important role in reducing consumption of chlorine and chlorine dioxide in paper and pulp industry (Tsujibo et al. 2001). Yeasts capable of producing glycosidases may be more suitable for the last application as they will require cloning of endo-xylanase gene only for this implication.

Kluyveromyces marxianus has been employed for production ofbiomass, enzymes and ethanol (Belem and Lee, 1998; Furlan et al. 2000). Recently production of $\beta$ xylosidase has been described in K. marxianus and other yeasts (Manzanares et al. 1999) but no detailed study is available on its production by wild or mutant cultures of $K$. marxianus. Xylose, xylobiose, synthetic $\beta$-xylosides and

* Corresponding author 
xylo-oligosaccharides are inducers of this enzyme in yeasts (Belem and Lee, 1998), but, like other enzymes, other carbon sources may serve as its inducers (Rajoka et al. 1997). The production of enzymes is influenced by induction and catabolite repression (de Groot et al. 2003). Carbon catabolite repression alters transcription and is regulated by CreA protein (catabolite repressible entities), a transcriptional repressor of glucose-repressible genes (de Vries et al. 1999). Increases in $\beta$-xylosidase production and redirection of transport system may enhance substrate utilization and product formation. 2-Deoxy-D-glucose (DG), a toxic glucose analogue, has frequently been employed to isolate glucose-deregulated mutants (Rajoka et al. 1998; Haq et al. 2001). In this work we report, the isolation of a derepressed mutant of $K$. marxianus which was also cycloheximide (protein synthesis inhibitor) (Gerlinger et al. 1997) and to establish the optimal culture conditions. This mutant, deregulated for $\beta$-xylosidase synthesis is also believed to have better transport system (Rajoka et al. 1998). This work reports regulation and hyper-production of $\beta$-xylosidase following growth of $K$. marxianus PPY125and its mutant M125on different carbon sources under optimized fermentation conditions (initial $\mathrm{pH}$ 5.5 , inoculum size $10 \%$, and yeast extract $0.3 \%$ ) with reference to its wild organism. Kinetic properties of partially purified enzyme were also studied to elucidate the thermo-tolerant/thermo-stable nature of this enzyme compared with those of thermostable or thermo stabilized enzymes reported in literature.

\section{MATERIALS AND METHODS}

\section{Organism and growth conditions}

Kluyveromyces marxianus PPY125, collected from Department of Plant Pathology, University of Agriculture, Faisalabad, Pakistan was maintained on malt extract plates and was grown in glucose yeast salts medium containing (g/l ) $\mathrm{KH}_{2} \mathrm{PO}_{4} 2.0,\left(\mathrm{NH}_{4}\right)_{2} \mathrm{SO}_{4} 5.0, \mathrm{MgSO}_{4} 7 \mathrm{H}_{2} \mathrm{O}$ 1.0, glucose 10 , and yeast extract 3.0 at $35^{\circ} \mathrm{C}$ with shaking at $150 \mathrm{rpm}$. The cultures were centrifuged (10,000 g, $10 \mathrm{~min})$, and used at $10 \%(\mathrm{v} / \mathrm{v})$ containing $1 \mathrm{mg}$ dry cells $/ \mathrm{ml}$.

\section{Selection of mutant}

The exposure of cell suspension $\left(2 \times 10^{9}\right.$ cells $\left./ \mathrm{ml}\right)$ to $\gamma$ irradiation (24 hrs) of 800 Gy caused approximately a 3 logarithmic reduction in viable cells. The resistant cells were expressed in yeast medium containing $160 \mu \mathrm{g}$ cycloheximide/ml. $+0.6 \%(\mathrm{w} / \mathrm{v})$ of 2-deoxy-D-glucose (a glucose analogue). After 48 hrs incubation, serial dilution of expressed cells was plated onto ortho-nitrophenyl $\beta$-Dxylopyranoside +cycloheximide +2-deoxy-D-glucose agar plates and putative mutant was selected after incubation at $50^{\circ} \mathrm{C}$ as described previously (Rajoka et al. 1997). The best mutant was designated M125 and tested for $\beta$-xylosidase production using different carbon and nitrogen sources.

Table 1. Comparative kinetic parameters of Kluyveromyces marxianus ppY125 and its mutant derivative (M 125) for $\beta$ xylosidase formation following growth on different substrates $(2 \%, \mathrm{w} / \mathrm{v})$ in yeast fermentation medium (pH 5.5) at $35^{\circ} \mathrm{C}$ up to $48 \mathrm{hrs}$ in time course studies.

\begin{tabular}{|c|c|c|c|c|}
\hline C-source & $\begin{array}{c}Y_{P / S} \\
(I U / g)\end{array}$ & $\begin{array}{l}\text { Specific } \\
\text { activity } \\
\text { (IU/mg) }\end{array}$ & $\begin{array}{c}Q_{p}^{* *} \\
(I U / l ~ h)\end{array}$ & $\begin{array}{c}Y_{\mathrm{P} / \mathrm{X}} \\
\text { (IUI.g cells) }\end{array}$ \\
\hline $\begin{array}{l}\text { Galactose } \\
\mathrm{P} \\
\mathrm{M}\end{array}$ & $\begin{array}{l}41.7 \mathrm{~h} \\
84.0 \mathrm{~g}\end{array}$ & $\begin{array}{l}1.8 \mathrm{~g} \\
3.7 \mathrm{f}\end{array}$ & $\begin{array}{l}11 g \\
23 f\end{array}$ & $\begin{array}{c}88 \mathrm{j} \\
166 \mathrm{i}\end{array}$ \\
\hline $\begin{array}{l}\text { Glucose } \\
\text { P } \\
M\end{array}$ & $\begin{array}{l}1.1 \mathrm{j} \\
4.1 \mathrm{i}\end{array}$ & $\begin{array}{l}0.2 \mathrm{i} \\
0.6 \mathrm{~h}\end{array}$ & $\begin{array}{l}1 \mathrm{i} \\
4 \mathrm{~h}\end{array}$ & $\begin{array}{l}2.0 \mathrm{I} \\
11 \mathrm{k}\end{array}$ \\
\hline $\begin{array}{l}\text { Xylose } \\
\text { P } \\
\text { M }\end{array}$ & $\begin{array}{l}192.0 d \\
391.2 \mathrm{a}\end{array}$ & $\begin{array}{l}15.8 \mathrm{c} \\
24.4 \mathrm{a}\end{array}$ & $\begin{array}{c}98 b \\
154 a\end{array}$ & $\begin{array}{l}333 e \\
653 a\end{array}$ \\
\hline $\begin{array}{l}\text { Cellobiose } \\
\text { P } \\
\text { M }\end{array}$ & $\begin{array}{l}191.0 d \\
389.1 \mathrm{a}\end{array}$ & $\begin{array}{l}15.0 d \\
23.2 b\end{array}$ & $\begin{array}{c}96 b \\
153 a\end{array}$ & $\begin{array}{l}315 f \\
425 b\end{array}$ \\
\hline $\begin{array}{l}\text { Lactose } \\
\mathrm{P} \\
\mathrm{M}\end{array}$ & $\begin{array}{l}122.2 \mathrm{f} \\
246.1 \mathrm{c}\end{array}$ & $\begin{array}{c}7.5 \mathrm{e} \\
14.8 \mathrm{~d}\end{array}$ & $\begin{array}{l}41 e \\
83 d\end{array}$ & $\begin{array}{l}244 h \\
365 c\end{array}$ \\
\hline $\begin{array}{l}\text { Sucrose } \\
\mathrm{P} \\
\mathrm{M}\end{array}$ & $\begin{array}{l}135.1 \mathrm{e} \\
273.1 \mathrm{~b}\end{array}$ & $\begin{array}{l}7.7 \mathrm{e} \\
15.0 \mathrm{~d}\end{array}$ & $\begin{array}{l}43 e \\
87 c\end{array}$ & $\begin{array}{l}267 g \\
361 c\end{array}$ \\
\hline
\end{tabular}

Each value is a mean of three replicates. Values followed by different letters differ significantly from each other at $p \leq 0.05$ using MstatC software ${ }^{* *} \mathrm{Q}_{\mathrm{p}}=$ volumetric productivity (IU/l.h), $\mathrm{Y}_{\mathrm{p} / \mathrm{X}}=$ Specific product yield (IU/g cells), $\mathrm{Y}_{\mathrm{p} / \mathrm{s}}=$ Product yield (IU/g substrate consumed).

\section{Enzyme production}

Growth kinetics of the organisms (in 1-l Erlenmeyer flasks in triplicate) was examined in the optimized medium $(\mathrm{pH}$ 5.5) containing glucose, cellobiose, lactose, sucrose and xylose (20 g/l each) as sole carbon sources and corn steep liquor as nitrogen source in place of ammonium sulphate unless mentioned otherwise (Rajoka et al. 2004). Inoculum was prepared in glucose medium at $35^{\circ} \mathrm{C}$ on a rotary shaker (150 rpm). The culture was centrifuged (10000 g, $30 \mathrm{~min})$, and used at $10 \%(\mathrm{v} / \mathrm{v})$ in saline containing $1 \mathrm{mg}$ dry cells $/ \mathrm{ml}$. All experiments were carried out at $35^{\circ} \mathrm{C}$ (unless otherwise mentioned) in triplicate in time course studies on a gyratory shaking-incubator up to 48-72 hrs. The cells were recovered as above, probe sonicated, fractioned as described earlier (Rajoka et al. 1997) and cell extract was assayed for intracellular enzyme activities while cell mass was determined gravimetrically. 

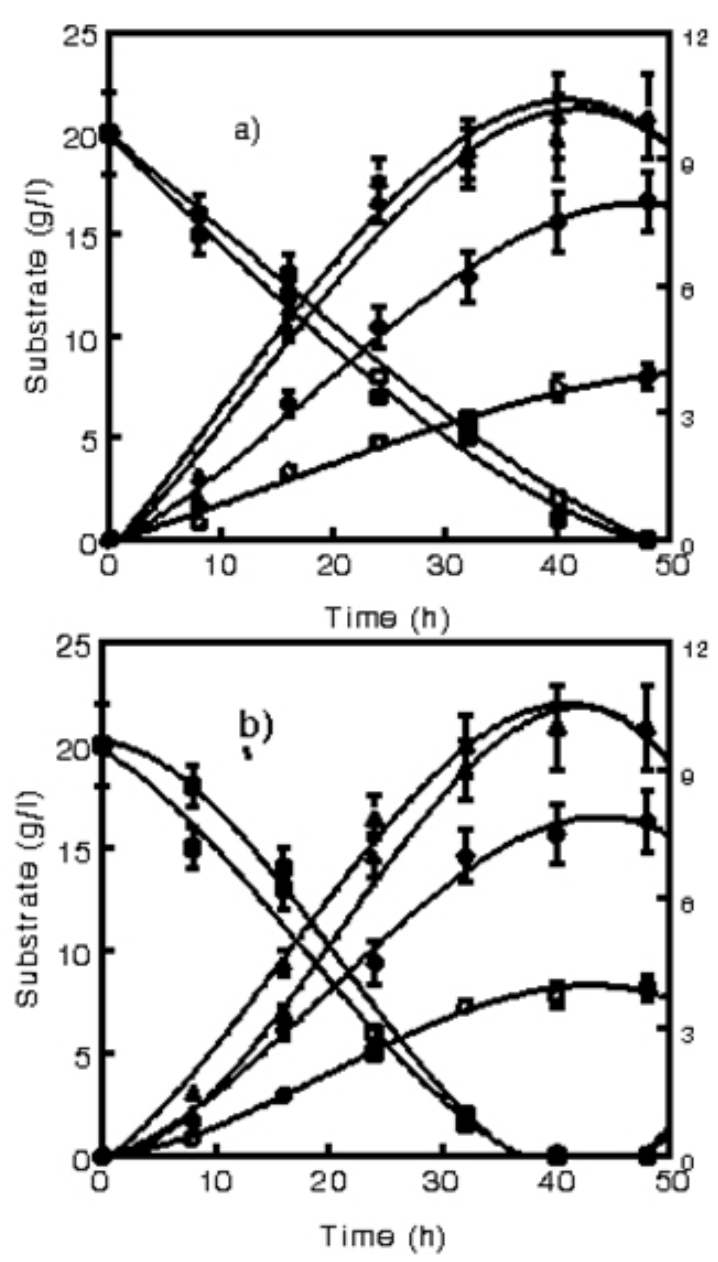

Figure 1. Kinetics of $\beta$-xylosidase production by $K$. marxianus PPY125 and its mutant M125 in shake flask fermentation of two representative substrates namely: (a) xylose, and

(b) cellobiose

Each $2 \%$ using yeast basal salt medium. The initial $\mathrm{pH}$ of the medium was 5.5 , inoculum size $10 \%$, and temperature $35^{\circ} \mathrm{C}$. $\mathrm{O}=\beta$-xylosidase activity IU per $\mathrm{ml}$ (open, parent; closed, mutant);

$\Delta=$ cell mass (g per l; open, parent; closed, mutant); $\square=$ substrate ( $\mathrm{g}$ per $\mathrm{I})$; open, parent; closed, mutant). Error bars represent standard deviation among three replicates.

\section{Effect of varying temperature on $\beta$-xylosidase production}

To calculate kinetic and thermodynamic values, the data of batch fermentation were gained by performing experiments (three runs) on xylose-corn steep liquor media on an orbital shaker $(150 \mathrm{rpm})$ at a temperature range $22-45^{\circ} \mathrm{C}(25,27$, $\left.30,32,35,37,40,43,45^{\circ} \mathrm{C}\right)$.

\section{Enzyme assays}

$\beta$-Xylosidase was assayed using $1 \mathrm{mM} p$-nitrophenyl- $\beta$-D- xylopyranoside as substrate in $50 \mathrm{mM}$ sodium acetate buffer, pH 5.0 (unless otherwise stated). One millilitre of the properly diluted enzyme sample was incubated with 1 $\mathrm{ml}$ of substrate solution at $40^{\circ} \mathrm{C}$ for $10 \mathrm{~min}$. The reaction was stopped by adding $2 \mathrm{ml}$ of $1 \mathrm{M}$ sodium carbonate. The liberated $p$-nitro phenol was measured at $400 \mathrm{~nm}$ with a spectrophotometer. One IU of $\beta$-xylosidase was defined as the amount of enzyme that released $1 \mu$ mol paranitrophenol per min under the assay conditions.

\section{Protein determination}

The proteins were determined by Bradford method (1976) using bovine serum albumin as the standard.

\section{Saccharides determination}

Total saccharides were determined after Miller (1959). Different saccharides were analyzed by HPLC (Perkin Elmer, USA) with Aminex column HPX-87H (300 x 78 $\mathrm{mm}$, Bio-Rad, Richmond, California) maintained at $45^{\circ} \mathrm{C}$ in a column oven. Sulphuric acid (0.002 N) served as a mobile phase at $0.6 \mathrm{ml} / \mathrm{min}$. The samples were detected using refractive index detector and quantified using Turbochron4 software of Perkin Elmer, USA.

Table 2. Kinetic and thermodynamic parameters for irreversible thermal inactivation of $\beta$-xylosidase from $K$. marxianus.

\begin{tabular}{|c|c|c|c|c|c|}
\hline $\mathbf{T}$ & $\underset{10^{-3} h^{-1}}{K_{d}}$ & $\begin{array}{l}t_{1 / 2} \\
\text { (h) }\end{array}$ & $\begin{array}{c}\Delta \mathbf{H}^{*} \\
\mathrm{~kJ} / . \mathrm{mol}\end{array}$ & $\underset{\mathrm{kJ} . / \mathrm{mol}}{\Delta \mathbf{G}^{*}}$ & $\begin{array}{c}\Delta \mathbf{S}^{*} \\
\text { J.mol/K }\end{array}$ \\
\hline $\begin{array}{l}323 \\
P \\
M\end{array}$ & $\begin{array}{c}3.0 \mathrm{~g} \\
2.31 \mathrm{~h}\end{array}$ & $\begin{array}{l}231 b \\
300 a\end{array}$ & $\begin{array}{l}54.3 a \\
48.3 b\end{array}$ & $\begin{array}{l}117.59 b \\
117.61 b\end{array}$ & $\begin{array}{l}-195.9 a \\
-214.6 h\end{array}$ \\
\hline $\begin{array}{l}328 \\
P \\
M\end{array}$ & $\begin{array}{l}4.2 e \\
3.5 f\end{array}$ & $\begin{array}{l}165 d \\
200 c\end{array}$ & $\begin{array}{l}54.3 a \\
48.3 b\end{array}$ & $\begin{array}{l}117.84 b \\
118.34 a\end{array}$ & $\begin{array}{l}-193.7 c \\
-213.5 g\end{array}$ \\
\hline $\begin{array}{l}333 \\
P \\
M\end{array}$ & $\begin{array}{c}11.0 c \\
9.2 d\end{array}$ & $\begin{array}{l}63 f \\
75 e\end{array}$ & $\begin{array}{l}54.2 a \\
48.2 b\end{array}$ & $\begin{array}{l}117.0 \mathrm{c} \\
117.5 \mathrm{c}\end{array}$ & $\begin{array}{l}-188.6 d \\
-208.1 f\end{array}$ \\
\hline $\begin{array}{l}338 \\
P \\
M\end{array}$ & $\begin{array}{l}69.3 a \\
36.5 b\end{array}$ & $\begin{array}{l}10 h \\
19 g\end{array}$ & $\begin{array}{l}54.2 a \\
48.2 b\end{array}$ & $\begin{array}{l}113.64 \text { e } \\
115.44 d\end{array}$ & $\begin{array}{l}-175.9 e \\
-198.9 b\end{array}$ \\
\hline
\end{tabular}

Each value is a mean of three observations. Values followed by different letters differ significantly at $p \leq 0.05$ using MstatC software.

$\mathrm{K}_{\mathrm{d}}=$ First order rate constant for inactivation;

$\Delta \mathrm{H}^{*}(\mathrm{~kJ} / \mathrm{M})=\mathrm{E}_{\mathrm{a}}(57 \mathrm{~kJ} / \mathrm{M})-\mathrm{RT}$ where $\mathrm{E}_{\mathrm{a}}$ is activation energy;

$\left.\Delta \mathrm{G}^{*}(\mathrm{~kJ} / \mathrm{M})=-\mathrm{RT} \ln \left\{\left(\mathrm{k}_{\mathrm{d}} \cdot \mathrm{h}\right) / \mathrm{k}_{\mathrm{B}} \cdot \mathrm{T}\right)\right\}$;

$\Delta S^{*}$ is entropy of irreversible inactivation and was calculated from $\Delta \mathrm{S}=\left(\Delta \mathrm{H}^{*}-\Delta \mathrm{G}^{*}\right) / \mathrm{T}$.

\section{Determination of kinetic parameters}

All kinetic parameters were determined as described 
previously (Lawford and Rousseau, 1993; Converti and Dominguez, 2001) in shake-flasks. Thermodynamics of enzyme production was performed as described previously (Converti and Dominguez, 2001). Kinetics of enzyme was performed as described previously (Siddiqui et al. 1997).

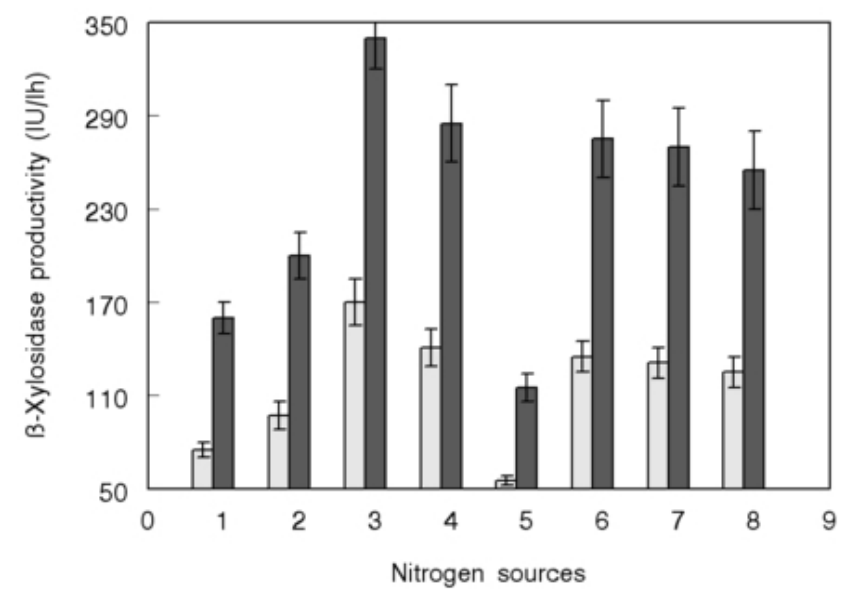

Figure 2. Effect of different nitrogen sources on $\beta$-xylosidase production by $K$. marxianus PPY125 (light squares) and its mutant M125 (dark squares). Organisms were grown on xylose $(20 \mathrm{~g} / \mathrm{l}, \mathrm{w} / \mathrm{v})$ containing different nitrogen sources $(1=$ ammonium nitrate; 2 = ammonium sulphate; $3=$ corn steep liquor; $4=$ soybean meal; $5=$ sodium glutamate; $6=$ sodium nitrate; $7=$ urea; and $8=$ peptone) at a rate of $1.1 \mathrm{~g} / \mathrm{l}$ equivalent to that contained in ammonium sulphate in triplicate. Flasks were harvested and processed as described in Materials and Methods. Each value is a mean of three independent experiments.Error bars represent standard deviation among three replicates.

\section{$\mathrm{pH}$ and temperature tolerance}

After 40 hrs of xylose fermentation, cells were harvested and $\beta$-xylosidase was extracted after probe-sonication according to Rajoka et al. (1997). The enzyme was partially purified by precipitation with $25 \%$ ammonium sulphate at $4^{\circ} \mathrm{C}$, and centrifuged. The precipitate was discarded and more ammonium sulphate was added in supernatant to make up its concentration up to $50 \%$ and left overnight at $4^{\circ} \mathrm{C}$. This time, precipitate was retained, dialyzed, and assayed after $30 \mathrm{~min}$ incubation in different buffers (containing phenyl methyl sulphonyl fluoride as protease inhibitor) as described earlier (Siddiqui et al. 1997).

The above enzyme containing $0.1 \mathrm{mM}$ PMSF was incubated at different temperatures for $30 \mathrm{~min}$ (Siddiqui et al. 1997) and remaining $\beta$-xylosidase activity was determined. $\beta$-xylosidase was re-dissolved in $50 \mathrm{mM}$ MES monohydrate buffer ( $\mathrm{pH}$ 5.5) and assayed for thermostability (Siddiqui et al. 1997). Activation energy $\left(E_{a}\right)$ was determined by using the data for optimum temperature. Arrhenius relationship was used to calculate the activation energy required by the enzyme to hydrolyze $p$-nitrophenyl- $\beta$-xylospyranoside as described earlier (Siddiqui et al.1997).

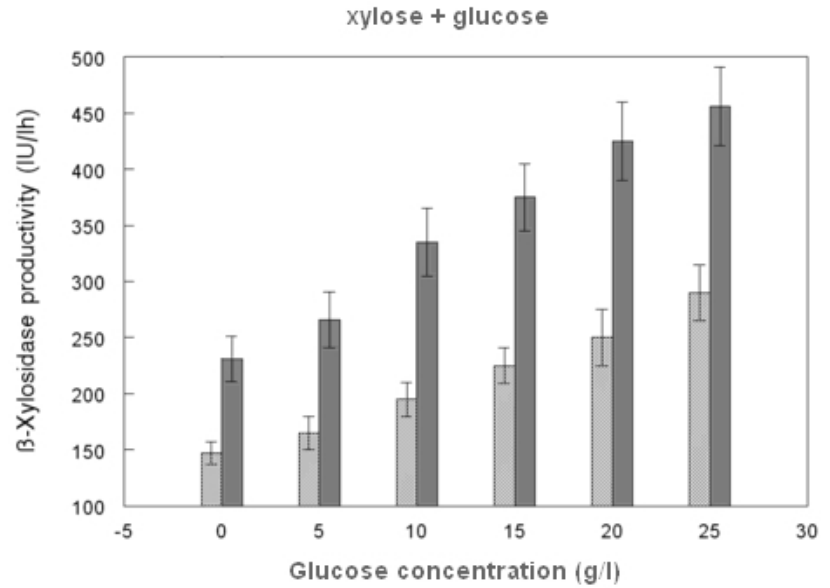

Figure 3. Effect of addition of glucose $(5,10,15,20$ and 25 $\mathrm{g} / \mathrm{l})$ in the xylose-corn steep liquor medium on volumetric productivity of $\beta$-xylosidase produced by the parental (light squares) and mutant (dark squares) cultures. Each value is a mean of three independent experiments. Error bars represent standard deviation among three replicates

\section{Thermodynamics of enzyme properties}

Thermal inactivation of the enzyme was determined by incubating the enzyme solutions in above buffer at a particular temperature. Aliquots were withdrawn at different times, cooled on ice for 3 hrs and assayed for enzyme activity at $40^{\circ} \mathrm{C}$ as described above. This procedure was repeated at 5 different temperatures ranging from 45$70^{\circ} \mathrm{C}$. The data were fitted to first order plots and analyzed. The first order rate constants $\left(\mathrm{k}_{\mathrm{d}}\right)$ were determined by linear regression of $\ln (\mathrm{V})$ vs. time of incubation ( $\mathrm{t}$ ). The thermodynamic data were calculated by rearranging the Eyring absolute rate equation to study the overall thermodynamic C: parameters in the range $45-70^{\circ}$

$\mathrm{K}_{\mathrm{d}}=\mathrm{T} . \mathrm{k}_{\mathrm{B}} / \mathrm{h} \mathrm{e}^{\Delta \mathrm{S} * / \mathrm{R}} \mathrm{e}^{\cdot \Delta \mathrm{H}^{*} / \mathrm{R} . \mathrm{T}}$

$\ln \left(\mathrm{k}_{\mathrm{d}} / \mathrm{T}\right)=\ln \left(\mathrm{k}_{\mathrm{B}} / \mathrm{h}\right)+\Delta \mathrm{S}^{*} / \mathrm{R}-\Delta \mathrm{H}^{*} / \mathrm{R} \cdot 1 / \mathrm{T}$

where $k_{d}, T, k_{B}, h, \Delta S^{*}, \Delta H^{*}$ and $R$ are specific reaction velocity, absolute temperature, Boltzmann constant, Planck's constant, entropy of activation, enthalpy of activation and gas constant respectively.

\section{Statistical analysis}

Treatment effects were compared by the protected least significant difference method and have been presented as two-factor factorial design in the form of probability $(p)$ using MstatC software

\section{RESULTS AND DISCUSSION}

\section{Kinetics of enzyme production following growth on different carbon sources}

Initial studies were performed to optimize substrate and 
substrate concentration. Among different substrates employed, $2 \%(\mathrm{w} / \mathrm{v})$ xylose supported the maximum enzyme activity, followed by cellobiose. Representative kinetics of enzyme production following growth on xylose (a) and cellobiose (b) respectively is presented in Figure 1. These curves indicated that bulk production of $\beta$-xylosidase was predominantly growth-associated. Application of Luedeking and Piret model (Aiba et al. 1973), however, indicated that the enzyme production was both growth- as well as non-growth-associated (results not presented) and confirmed the work of Inchaurrondo et al. (1994). The efficacy of inducers can be determined by both their actual concentration in side the cell and their binding affinity to regulatory macromolecules (Perez-Gonzalez, 1998; La Grange et al. 2001). This was determined by using inducers (xylose and disaccharides) and non-inducer (glucose). Specific enzyme yield $\left(\mathrm{Y}_{\mathrm{P} / \mathrm{X}}\right)$, in the case of wild culture, was $333 \mathrm{IU}$ per g cells on xylose, and only 2 IU per g cells (as basal enzyme activity) on glucose (non- inducer). The induction ratio, defined as the ratio of activity on inducer to basal activity on non-inducer, was 165.5 and 140.0 on xylose and disaccharides (Table 1) in wild cells respectively and that mutant was significantly (up to 2.0fold) improved for product formation parameters. The results of Table 1 suggest that biosynthesis of $\beta$-xylosidase was regulated by an induction mechanism that enhanced the specific enzyme yield $\left(\mathrm{Y}_{\mathrm{P} / \mathrm{X}}\right)$ of $\beta$-xylosidase up to 166.5fold in induced over non-induced cultures in wild cells and up to 59-fold in mutant cells. There were no significant differences in the values of specific growth rate, specific substrate uptake rate and volumetric substrate uptake rates during growth on all carbon sources in the wild and mutant organisms (results not presented) still mutant 125 differed significantly ( $p \leq 0.05$ ) over its wild cells for formation of $\beta$-xylosidase parameters. In the wild cells, the values of specific substrate uptake rate $\left(\mathrm{q}_{\mathrm{s}}\right)$ from disaccharides $(0.587$ $\pm 0.162)$, xylose ( $0.73 \mathrm{~g} / \mathrm{g} . \mathrm{h})$, and glucose $(0.95 \mathrm{~g} / \mathrm{g} . \mathrm{h})$ were significantly different from each other (results not presented) and product formation kinetic parameters (Table 1) were higher on xylose, followed by disaccharides, galactose and glucose. Thus product formation was inversely related to the values of $\mathrm{q}_{\mathrm{s}}$. These studies indicated that product formation was regulated by growth-dependent repression mechanism and confirmed the work of $\mathrm{Li}$ and Ljungdahl, 1994).

Best yield of $\beta$-xylosidase (Table 1) on xylose (in both organisms) is in good agreement with that reported by Perez-Gonzalez (1998). In other enzyme systems, disaccharides or high molecular weight substrates have been found to be the best inducers of $\beta$-xylosidase (Rajoka et al. 1997). Maximum values of product formation kinetic parameters in the mutant culture (Table 1) are higher than the calculated values on several Saccharomyces cerevisiae recombinants harboring heterologous genes of $\beta$-xylosidase from Aspergillus niger, different bacteria and A. nidulans (Perez-Gonzalez et al. 1998; La Grange et al. 2001), and Cellulomonas and other strains (Rajoka et al. 1997).

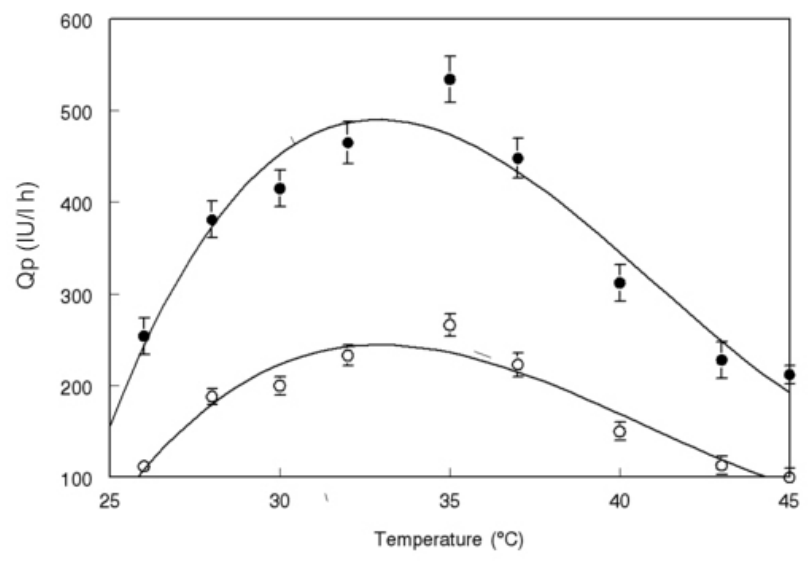

Figure 4. Effect of temperature on volumetric productivity (IU/lh) of $\beta$-xylosidase during growth of $K$. marxianus PPY125and its mutant (M125) cultures on xylose (2\%) medium (pH 5.5). The organisms were grown as described in Methods. Each value is a mean of three independent experiments. Error bars represent standard deviation among three replicates.

Different nitrogen sources were employed to give equimolar amount of nitrogen maintained at $1.1 \mathrm{~g} / \mathrm{l}$, and xylose as carbon source (Figure 2). Corn steep liquor and soy bean were the best nitrogen sources followed by sodium nitrate, urea and peptone. (Rajoka et al. 1998) observed that an increase in $\mathrm{NaNO}_{3}$ concentration greatly increased cellulase synthesis in Cellulomonas biazotea.

Catabolite repression plays an important role in the regulation and secretion of inducible enzymes. Such repression effect has been observed in several organisms (Li and Ljungdahl, 1994; Ponce-Noyola and de la Torre, 2001). Production of $\beta$-xylosidase by the organism on xylose-yeast medium using corn steep liquor as nitrogen source when glucose was added $(5,10$ to $15 \mathrm{~g} / \mathrm{l}$ final concentration respectively) at the time of inoculation (Figure 3), showed that there was significant enhancement in the enzyme synthesis rate in both wild and mutant cells and there was no inhibition of enzyme synthesis. Mixed inductive or repressive effect has been observed in other organisms (Li and Ljungdahl, 1994; Ponce-Noyola and de la Torre, 2001). When corn steep liquor was used as a nitrogen source, no inhibitory effect was observed when even glucose served as the carbon source. Corn steep liquor may not have supported the formation of Cre A protein as observed in its absence (Lockington et al. 2002).

\section{Effect of initial temperature of fermentation on $\beta$ - xylosidase production}

Temperature is known to affect microbial growth, cell biomass and consequently it may also affect $\beta$-xylosidase production. Maximum specific productivity $\left(\mathrm{q}_{\mathrm{p}}\right)$ of $\beta$ xylosidase occurred at fermentation temperature of $35^{\circ} \mathrm{C}$ (Figure 4). At higher or lower temperature, $\beta$-xylosidase 
production by the cells was decreased. At lower temperature, the transport of substrate across the cells is suppressed and lower yield of products are attained (Aiba et al. 1973). At higher temperature, the maintenance energy requirement for cellular growth is high due to thermal inactivation of the enzymes of the metabolic pathway (Aiba et al. 1973) resulting in lower amount of product formation. The productivity decline observed at high temperature could be due to the reversible denaturation of enzyme formed on optimized-medium as described previously (Converti and Dominguez, 2001).

\section{Enzyme properties}

The enzyme showed maximum activity at $55^{\circ} \mathrm{C}$. Thermal inactivation followed first order kinetics in the presence of PMSF. Half life of the enzyme was 231, 165 and $63 \mathrm{hrs}$ at $50^{\circ} \mathrm{C}, 55^{\circ} \mathrm{C}$ and $60^{\circ} \mathrm{C}$ respectively (calculated as described by Rashid and Siddiqui, 1998), compared with half life of $4.85 \mathrm{~h}$ at $65^{\circ} \mathrm{C}$ exhibited by E. coli recombinant harboring heterologous $\beta$-xylosidase genes from thermophilic organisms (Tsujibo et al. 2001) and confirmed the thermostability of mutant derived $\beta$-xylosidase.

\section{Thermostability}

The protein mid-point inactivation temperature, activation energy, values of enthalpy and entropy of enzyme inactivation are considered potential determinants of enzyme thermostability. The protein mid-point inactivation temperature $\left(T_{m}\right)$ was $65^{\circ} \mathrm{C}$ (results not shown). For wildtype nuclease at $\mathrm{pH} 7.0$, the $\mathrm{T}_{\mathrm{m}}$ of 53.3 was obtained (Shortle et al. 1988). Optimum activity was at $50^{\circ} \mathrm{C}$ for an incubation of 10 min while compensation temperature was $68^{\circ} \mathrm{C}$ (results not shown) which was higher than that for thermostable or thermo stabilized mutants (Chen et al.1994; Rashid and Siddiqui, 1998; Declerck et al. 2003).

Activation energy for catalysis of pNBX $\beta$ was $57 \mathrm{~kJ} / \mathrm{mol}$ (results not presented) which is significantly lower than required by native or chemically modified $\beta$-glucosidases (389 or $174 \mathrm{~kJ} / \mathrm{mol}$ ) (Rashid and Siddiqui, 1998) and thermostable glucoamylase from a thermostabilized mutant derivative of Aspergillus awamori (Chen et al. 1994).

\section{Thermodynamic studies of $\beta$-xylosidase}

Thermal inactivation occurs in two steps as shown below:

$\mathrm{N} \leftrightarrow \mathrm{U} \rightarrow \mathrm{I}$

where $\mathrm{N}$ is the native, $\mathrm{U}$ is the unfolded enzyme which could be reversibly refolded upon cooling and I is the inactivated enzyme formed after prolonged exposure to heat and therefore can not be recovered on cooling.
The thermal denaturation of enzymes is accompanied by the disruption of non-covalent linkages, including hydrophobic interactions, with concomitant increase in the enthalpy of activation (Daniel, 1996). The opening up of the enzyme structure is accompanied by an increase in the disorder, randomness or entropy of activation (Vieille and Zeikus, 1996). Thermal inactivation of the enzyme was determined by incubating the enzyme solutions in sodium acetate buffer (pH 5.5) at a particular temperature. Aliquots were withdrawn after every $15 \mathrm{~min}$, cooled on ice and assayed for enzyme activity at $40^{\circ} \mathrm{C}$ as described in Materials and methods. The thermodynamic data were calculated as described previously (Rashid and Siddiqui,

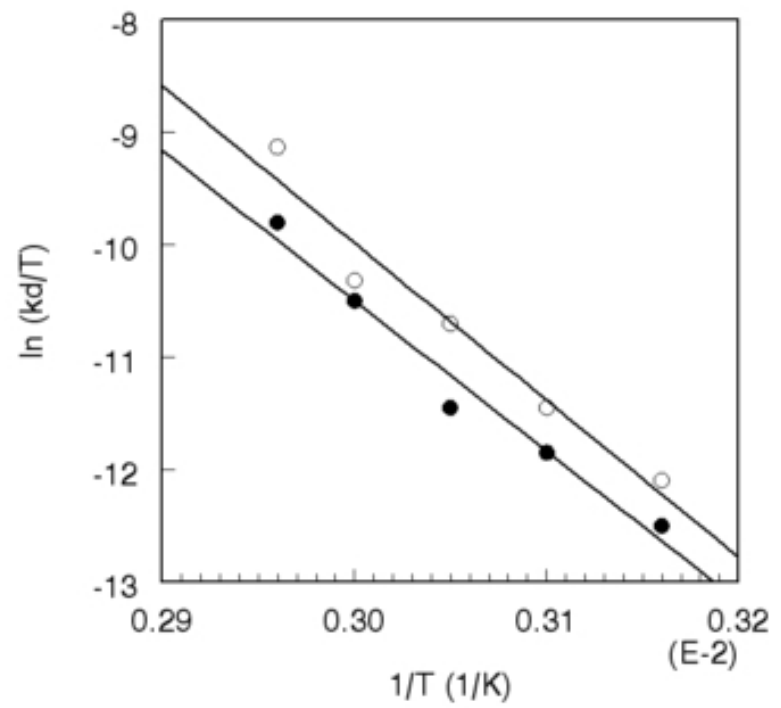

Figure 5. Arrhenius plots for calculating enthalpy and entropy for reversible inactivation of $\beta$-xylosidase. They were calculated by applying the equation 2 in Materials and Methods (Aiba et al. 1973).

The value of $\Delta \mathrm{H}^{*}$ was calculated from slope of the straight line between $\ln \left(k_{d} / T\right)$ and $1 / T$ while $\ln \left(k_{B} / h\right)+\Delta S^{*} / R=$ Intercept on ordinate. $\mathrm{k}_{\mathrm{B}}, \mathrm{h}$, and $\mathrm{R}$ are $1.38 \times 10^{-23} \mathrm{JK}^{-1}, 6.63 \times 10^{-34} \mathrm{~J} . \mathrm{S}$ and $8.314 \mathrm{JK}^{-1} \mathrm{~mol}^{-1}$ respectively (Rahsid and Siddiqui, 1998).

1998) in the range $45-70^{\circ} \mathrm{C}$ (Figure 5).

The values of thermodynamic parameters (calculated from Figure 5) were $73 \mathrm{~kJ} / \mathrm{mol}$ and $60 \mathrm{~J} / \mathrm{mol} \mathrm{K}$, for $\Delta \mathrm{H}^{*}$ (enthalpy of deactivation) and $\Delta \mathrm{S}^{*}$ (entropy of deactivation) respectively for the mutant-derived enzyme. These values were significantly lower than those for native enzyme (99 kJ/ mol and $75 \mathrm{~J} / \mathrm{mol} \mathrm{K}$ respectively). The values of $\Delta S^{*}$ and $\Delta H^{*}$ of $\beta$-glucosidase from a thermophilic culture of Aspergillus wentii (Kvesitadze et al.1990) were $125 \mathrm{~kJ} / \mathrm{mol}$ and $65 \mathrm{~J} / \mathrm{mol} \mathrm{K}$ respectively. The test enzyme required significantly lower energy values for inactivation (a positive effect) as compared with that required by above organism, therefore, up to $70^{\circ} \mathrm{C}$, the enzyme was substantially thermostable. These values are 
also significantly lower than those reported on thermostable glucoamylase by a thermo stabilized mutant of A. awamori (Chen et al.1994). When enthalpy and entropy values for inactivation were calculated at each temperature, $\Delta S^{*}$ had negative values for both wild- and mutant-derived $\beta$ xylosidase (Table 2). This suggested that there was negligible disorder ness as was that of $\beta$-glucosidase from A. wentii or $\alpha$-amylase from Bacillus licheniformis as revealed by its negative $\Delta \mathrm{S}^{*}$ at $80^{\circ} \mathrm{C}$ (Violet and Meunier, 1989; Declerck et al. 2003) and other thermostable enzyme by other organisms (Chen et al. 2000; Chen and Stites, 2001; Tsujibo et al. 2001). Similarly enzyme was stable at $\mathrm{pH}$ 5.0-7.0 (results not presented) and corroborated the work of Tsujibo et al. 2001 who observed $\mathrm{pH}$ 6.0-7.0 optimum for $E$. coli recombinants.

\section{CONCLUDING REMARKS}

From the data on induction studies, it was concluded that the availability of an inducer in the fermentation medium is advantageous for $\beta$-xylosidase production. $\beta$-Xylosidase was also induced by cellobiose, sucrose, and lactose. Lactose in cheese whey or sucrose in molasses may be economically viable inducers for mass production of this enzyme. Further studies are needed to develop a continuous system for enzyme production which would fulfill process requirement. Thermodynamic studies provided sufficient insight into the thermostability of the enzyme and may be due to accompanying chaperone activity. Endo- $\beta$-xylanase and $\beta$-xylosidase act in synergism to breakdown xylanlignin complex in paper and pulp industry (Tsujibo et al. 2001) K. marxianus produces $\beta$-xylosidase with out any accompanying cellulases (Belem and Lee, 1998) This organism produces $\beta$-galactosidase, $\beta$-glucosidase, and pectinase as well (Belem and Lee, 1998) and may be suitable for biobleaching of pulps if xylanase gene could be incorporated in $K$. marxianus as reported by other authors (La Grange et al. 2001).

\section{ACKNOWLEDGMENTS}

Technical assistance of Riaz Shahid and research facilities provided by Director General NIBGE/NIAB are gratefully appreciated.

\section{REFERENCES}

AIBA, S.; HUMPHREY, A.E. and MILLIS, N.F. Biochemical Engineering. $2^{\text {nd }}$ Edition, New York. Academic Press. 1973. p. 92- 127.

BELEM, M.A.F. and LEE, B.H. Production of bioingredients from Kluyveromycess marxianus grown on whey: an alternative. Critical Reviews in Food Science and Nutition, October 1998, vol. 38, no.1, p. 565-598.

CHEN, H.; BAKIR, U.; REILLY, P.J. and FORD, C.
Increased Ala mutant thermostability of Asn 182 Aspergillus awamori glucoamylase. Biotechnology and Bioengineering, January 1994, vol. 43, no. 1, p. 101-105.

CHEN, J.; LU, Z.; SAKON, J. and STITES, W.E. Increasing the thermostability of staphylococcal nuclease: implications for the origin of protein thermostability. Journal of Molecular Biology, January 2000, vol. 303, no. 1, p. 125-130.

CHEN, J. and STITES, W.E. Higher-order packing interactions in triple and quadruple mutants of staphylococcal nuclease. Biochemistry, November 2001, vol. 40, no. 11, p. 14012-14019.

CONVERTI, A. and DOMINGUEZ, J.M. Influence of temperature and $\mathrm{pH}$ on xylitol production from xylose by Debarryomyces hansenii. Biotechnology and Bioengineering October 2001, vol. 75, no. 1, p. 39-45.

DANIEL, R.M. The upper limits of enzyme thermal stability. Enzyme and Microbial Technology, January 1996, vol. 19, no. 1, p. $74-79$.

DECLERCK, N.; MACHIUS, M.; JOYET, P.; WIEGAND, G.; HUBER, R. and GAILLARDIN, C. Hyperthermostabilization of Bacillus licheniformis alphaamylase and modulation of its stability over a 50 degrees $C$ temperature range. Protein Engineering, January 2003, vol. 16, no. 1, p. 287-293.

DE GROOT, M.J.; VAN, D.E.; VONDERVOORT, P.J.; DE, VRIES, R.P.; VANKUYK, P.A. RUIJTER, G.J. and VISSER, J. Isolation and characterization of two specific regulatory Aspergillus niger mutants show antagonistic regulation of arabinan and xylan metabolism. Microbiology, May 2003, vol. 149, no. 5, p.1183-1191.

DE VRIES, R.P.; VISSER, J. and DE GRAAFF, L.H. CreA modulates the XlnR-induced expression on xylose of Aspergillus niger genes involved in xylan degradation. Research in Microbiology,February 1999, vol.150, no. 2, p. 281-285.

FURLAN, A.S.; SCHNEIDER, A.S.L.; MERCKLE, R.; CARVALHO-JOHANS, M.F. and JONAS, R. Formulation of lactose-free, low-cost culture medium for the production of $\beta$-galactosidase by Kluyveromyces marxianus. Biotechnology Letters, July 2000, vol. 22, no. 7, p. 589593.

GERLINGER, U.M.; GUCKEL, R.; HOFFMANN, M.; WOLF, D.H. and HILT, W. Yeast cycloheximide-resistant crl mutants are proteasome mutants defective in protein degradation. Molecular Biology of the Cell, December 1997, vol. 8:, no. 12, p. 2487-2499.

HAQ, I.;KHURSHID, S.; ALI, S.; ASHRAF, H.; 
QADEER, M.A. and RAJOKA, M.I. Mutation of Aspergillus niger for hyperproduction of citric acid following fermentation of blackstrap molasses. World Journal of Microbiology and Biotechnology, February 2001, vol. 17, no. 1, p. 35-37.

INCHAURRONDO, V.A.; YANTORNO, OM. and VOGET, C.E. Yeast growth and $\beta$-galactosidase production during aerobic batch cultures in lactose-limited synthetic medium. Process Biochemistry, January 1994, vol. 29, no. 1, p. 47-55.

KVESITADZE, G. I.; SVANBIDEZ, R. S.; TSUPRUN, V. L.; NIZHARADZE, D.N. and BUACHIDZE, T.S.H. Quaternary structure and properties of enzyme, $-\beta$ glucosidase, isolated from a thermophilic culture of Aspergillus wentii. Bioorganicheskaya Khimiya, July 1990, no. 16 , no. 7 , p. 881-888.

LA GRANGE, D.C.; PRETORIUSM I.S.; CLAEYSSENS, M. and VAN ZYL, W.H. Degradation of xylan to D-xylose by recombinant Saccharomyces cerevisiae co expressing the Aspergillus niger beta-xylosidase $(x \ln \mathrm{D})$ and the Trichoderma reesei xylanase ii (xyn2) genes. Applied and Environmental Microbiology, 2001, vol. 67, no. 12, p. 5512-5519.

LAWFORD, H.G. and ROUSSEAU, J.D. Mannose fermentation by ethanologenic recombinants of Escherichia coli. Biotechnology Letters, June 1993, vol. 15, no. 6, p. 615-620.

LI, X-L. and LJUNGDAHL, L.G. Cloning, sequencing and regulation of a xylanase gene 2 from the fungus Aureobasidium pullulans Y-2311-1. Applied and Environmental Microbiology, September 1994, vol. 60, no. 9, p. 3160-3166.

LOCKINGTON, R.A.; RODBOURN, L.; BARNETT, S.; CARTER, C.J. and KELLY, J.M. Regulation by carbon and nitrogen sources of a family of cellulases in Aspergillus nidulans. Fungal Genetics and Biology,November 2002, vol. 37, no.2., p. 190-196.

MANZANARES, P.; RAMON, D. and QUEROL, A. Screening of non-Saccharomyces wine yeasts for production of $\beta$-xylossidase activity. International Journal of Food Microbiology, February 1999, vol. 46, no.2, p. 105112.

MILLER, G.L. Use of dinitrosalisylic acid (DNS) for determination of reducing sugars. Analytical Chemistry,March1959, vol. 31, no. 3, p. 426-428.

PEREZ-GONZALEZ, J.A.; VAN PEIJ, N.N.; BEZOEN, A.; MACCABE, A.P.; RAMON, D. and DEGRAFF, L.H. Molecular cloning and transcriptional regulation of the Aspergillus nidulans xynD gene encoding a betaxylosidase. Applied and Environmental Microbiology,
April 1998, vol. 64, no.4, p. 1412-1419.

PONCE-NOYOLA, T. and DE LA TORRE, M. Regulation of cellulases and xylanases in a derepressed mutant of Cellulomonas flavigena growing on sugar-cane bagasse in continuous cultures. Bioresource Technology,July 2001, vol. 78, no. 3, p. 285-291.

RAJOKA, M.I.; BASHIR, A. and MALIK, K.A. Mutagenesis of Cellulomonas biazotea for enhanced production of xylanases. Bioresource Technology, January 1997, vol. 62, no.1, p. 99-108.

RAJOKA, M.I.; BASHIR, A.; HUSSAIN, M-R.A. and MALIK K.A. Mutagenesis of Cellulomonas biazotea for improved production of cellulases. Folia Microbiologica, January 1998, vol. 43, no. 1, p. 15-22.

RAJOKA, M.I.; LATIF, F., KHAN, S. and SHAHID, R. Kinetics of improved productivity of $\beta$-galactosidase by a cycloheximide-resistant mutant of Kluyveromyces marxianus Biotechnology Letters, May 2004, vol. 26, no. 9 p. 741-746.

RASHID, M.H. and SIDDIQUI, K.S. Thermodynamic and kinetic study of -glucosidase from stability of the native and chemically modified $\beta$ Aspergillus niger. Process Biochemistry, January1998, vol. 33, no. 2, p. 109-115.

SHORTLE, D.; MEEKER, A.K. and FREIRE, E. Stability mutants of staphylococcal nuclease l: Large compensating enthalpy-entropy changes for the reversible denaturation reaction. Biochemistry, June 1988, vol. 27, no. 13, p. 47614768.

SIDDIQUI, K.S.; RASHID, M.H. and RAJOKA, M.I. Kinetic analysis of the active site residues of an intracellular $\beta$-glucosidase from Cellulomonas biazotea. Folia Microbiologica, January 1997, vol. 42, no. 1, p. 5358.

TSUJIBO, H.; TAKADA, A.; KOSAKA, M.; MIYAMOTO, K. and INAMORI, Y. Cloning, sequencing, and expression of the gene encoding an intracellular $\beta$-Dxylosidase from Streptomyces thermoviolaceus OPC-520. Bioscience Biotechnology and Biochemistry, August 2001, vol. 65, no. 8, p. 1824-1831.

VIEILLE, C. and ZEIKUS, J.G. Thermozymes: identifying molecular determinants of protein structural and functional stability. Trends in Biotechnology, January 1996, vol. 14, no. 1, p. 183190.

VIOLET, M. and MEUNIER, J.C. Kinetic study of the irreversible thermal denaturation of Bacillus licheniformis $\alpha$-amylase. Biochemistry Journal,November 1989, vol. 26, no. 3, p. 665-670. 